\title{
THE APPLICATION OF THE OEE METHOD FOR THE ASSESSMENT OF BLAST FURNACE EFFECTIVENESS
}

\author{
Edyta KARDAS \\ Czestochowa University of Technology, Czestochowa, Faculty of Production Engineering and Materials \\ Technology, UI. Dąbrowskiego 69, 42-201Czestochowa,Poland, EU, edyta.kardas@pcz.pl
}

https://doi.org/10.37904/metal.2020.3653

\begin{abstract}
Blast furnace process is the basic process of pig iron production. This kind of device has a very large volume, so every day it produces significant quantities of the products. Therefore, the effectiveness of this device should be tested regularly. It helps to find causes lowering the effectiveness and optimize the production process. The main goal of the paper is the presentation of results of Overall Equipment Effectiveness of blast furnace conducted in one of Polish steelworks and the causes lowering the value of effectiveness. The analysis covers the period of one calendar year.
\end{abstract}

Keywords: Blast furnace, pig iron, effectiveness, OEE

\section{INTRODUCTION}

One of the basic goals of every company is the optimal use of its resources. The analysis of their use can be done with many technical and economic indicators, which include productivity, efficiency or effectiveness. Many authors closely associate the concept of productivity with other economic indicators, among which economics (efficiency) as well as active action (effectiveness) are of particular importance [1]. Effectiveness is differently classified in the literature. It may relate to the economy, enterprise, process, equipment, resources, finance, decision, management, investment, etc. Therefore, the terms appear in the literature such as: economic effectiveness, management effectiveness, business effectiveness, process effectiveness, technical effectiveness or financial effectiveness [2].

The blast furnace is the first and very often the most critical step in the production of iron and steel. The blast furnace process is very complicated and involves huge streams of materials and energy. The main advantage of the blast furnace process is its high production efficiency and high thermal efficiency, while the disadvantage is the need for very expensive coke [3]. The effectiveness of the blast furnace depends on many factors, some of them can decrease its value, so they must be identified and eliminated.

The main goal of the paper is the presentation of results of Overall Equipment Effectiveness of blast furnace conducted in one of Polish steelworks and the causes lowering the value of effectiveness. The paper presents the analysis of selected indicators of the effectiveness of this device. The indicators were chosen that allowed to assess the accessibility, utilization, quality and total effectiveness. The author pointed out the main causes affecting the low values of indicators. The analysis covers one calendar year.

\section{OVERALL EQUIPMENT EFFECTIVENESS - METHODOLOGY OF THE RESEARCH}

Overall Equipment Effectiveness indicator (OEE) is one of key methods used in Total Productive Maintenance. It helps to assess the work of equipment and find the causes of inappropriate level of the effectiveness. The Overall Effectiveness is a measure of efficiency of machine (device) calculated on the basis of its performance using three basic elements [4]: 
- accessibility in terms of active operation of the machine,

- $\quad$ use in terms of planned percentage of the duty,

- $\quad$ quality of products made by the machine (device).

Knowledge of this indicator allows to evaluate the effectiveness of use of equipment and consequently the whole process from viewpoint of machinery and equipment [5]. It helps to identify main problems of companies and calculates the benefits connected with elimination various problems [6]. To determine the value of OEE data connected with: available time, machines working tine, interruption in their work, level of production, unit production time and quantity of non-conformance production should be taken into account.

The method of calculating the OEE indicator can be presented schematically, according to the following formulas [5-9]:

- $\quad$ Accessibility Indicator $(A I)$ - determines the percentage of machine operation time in the total time a machine could work. This relationship can be described by the formula:

$A I=\frac{\text { shift } \text { work fund-total downtime }}{\text { shift } \text { work fund }}$

Where total downtime includes renovation time (planned downtime), failure time, tooling change time, adjustment time and time to replace components.

- $\quad$ Operating Speed Indicator $(O S I)$ - the ratio of time of manufacture of the product unit considered its ideal to real value. The relationship can be expressed as follows:

$O S I=\frac{\text { ideal time of manufacture of the product }}{\text { real time of manufacture of the product }}$

- Useful Time Indicator (UTI) - the ratio of the actual production time of the products during the device's operation, expressed by the formula:

$U T I=\frac{\text { quantity of productucion.real time of naufacture of the product }}{\text { shift work fund-total downtime }}$

- Utilization Indicator $(U I)$ - product of operating speed indicator and useful time indicator, expressing the use of device's working time:

$U I=O S I \cdot U T I$

- Quality Indicator $(Q I)$ - percentage of production meeting the quality requirements, expressed by the formula:

$Q I=1-$ percentage of nonconforming products

- Overall Equipment Effectiveness indicator $(O E E)$ - measure of effectiveness of the use of the device, expressed by the formula:

$O E E=A I \cdot U I \cdot Q I$

Literature [5-9] shows World Class OEE values: OEE indicator should be at the level of $85 \%$ as the product of accessibility (90\%), utilization (95\%) and quality (99.9\%). It is desired value, bur the research around the world shows that the average of OEE is app. $60 \%$ and is much lower than World Class vale $[8,9]$. Some 
authors say that average value of such indicators on the level of $40-60 \%$ is medium, while $20-40 \%-$ low [6].

In the analysis information from blast furnace department of one of Polish steelworks were used. The analysis covers the monthly data in the period of one calendar year. On the beginning the information about the work of device was collected, then main indicators were calculated according to formulas (1) - (6). During the analysis of results, the identification of basic causes was carried out.

\section{THE ANALYSIS OF RESULTS}

The analysis of Overall Equipment Effectiveness was conducted. Values of parameters of the analysis was calculated. Main parameters are presented in Figures 1 - 4.

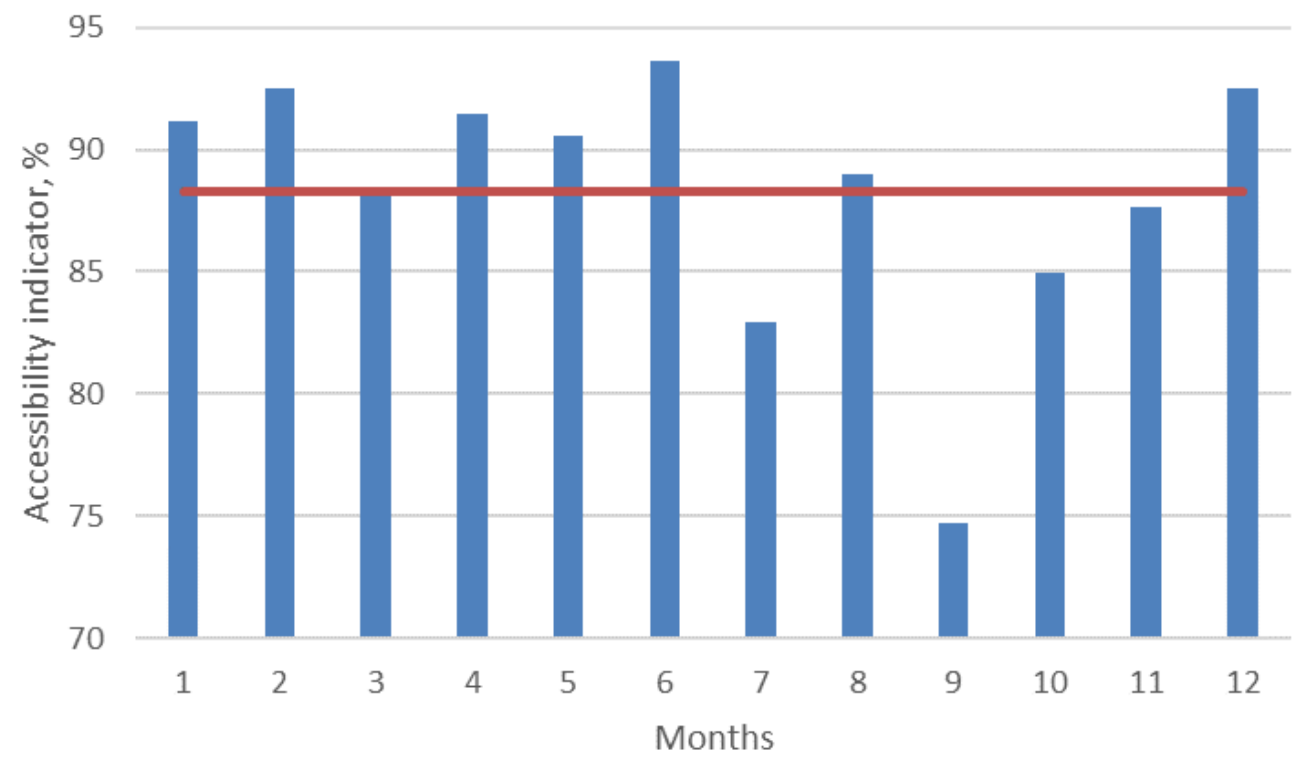

Figure 1 Value of Accessibility Indicator of tested blast furnace during study period (own study based on [10])

Figure 1 presents values of Accessibility Indicator for tested blast furnace in the study period. As it can be seen the average accessibility of this device was on the level of $88.3 \%$ (standard value is app. $90 \%$ ) and underwent significant changes between 74.4 and $93.6 \%$. The lowest value was noticed in month 9 , while the highest in month 6 . It must be underlined that value of $90 \%$ were exceeded in 6 months. Lower values of the indicator were caused by many various factors, according which some of them should be motioned $[3,11]$ :

- The age of the device - the tested blast furnace is not a new device, it underwent an interim overhaul a few years ago, but all the time during the work of the device current renovations must be carried out, because they enable the efficient work for longer time.

- $\quad$ Problems with demand for pig iron - the demand of pig iron depends mainly on the main customer steelwork department. Only small percentage of production is sold to the external customers. Any disruption to the steelworks causes problems with the transport of pig iron to steelwork department, in this situation it is kept in the blast furnace for longer.

- Technological and mechanical breaks - despite the planning medium and current renovations, there are various failures quite often, it can involve the need to repair the device or replace part. 


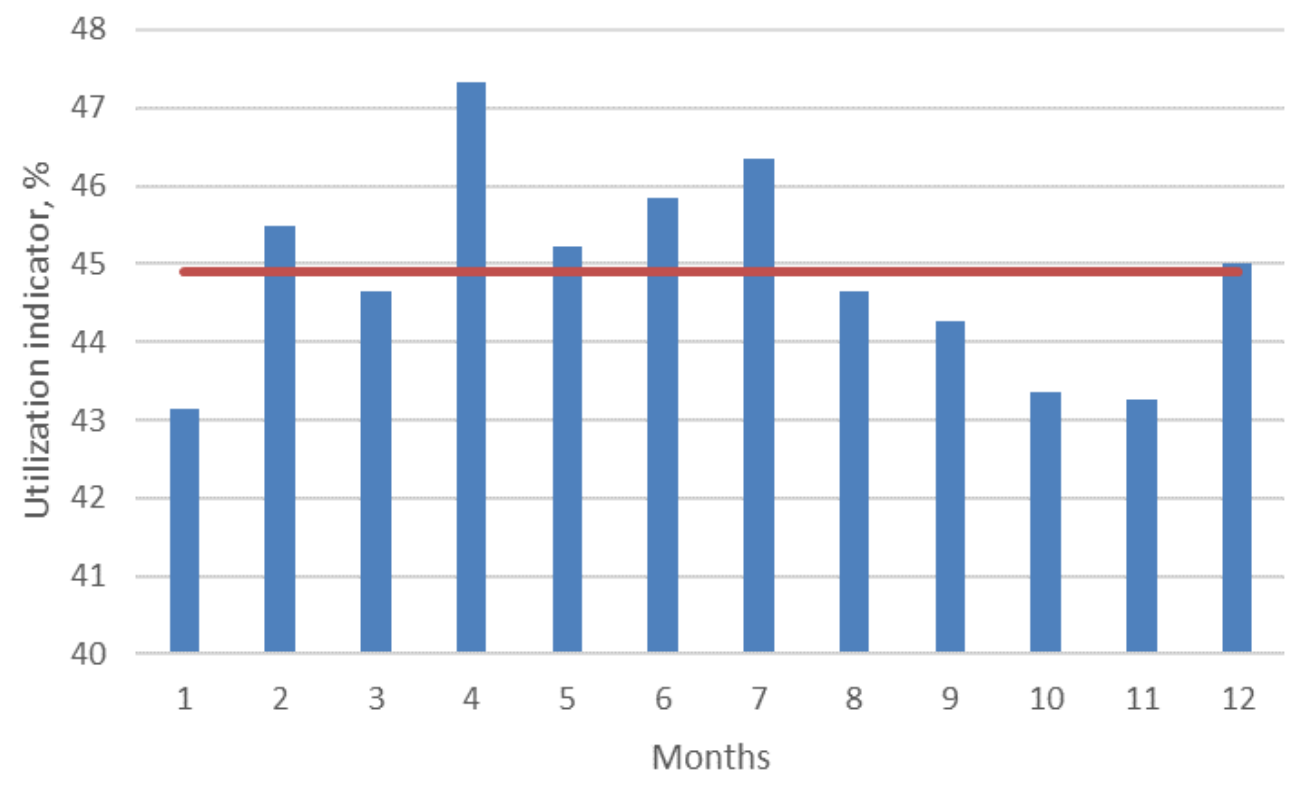

Figure 2 Value of Utilization Indicator of tested blast furnace during study period (own study based on [10])

According to the results presented in Figure 2 it can be said that the average value of Utilization Indicator was on the level of $45 \%$ and changed in range from 43.1 to $47.3 \%$. It was significantly lower than standard value of this indicator. The highest value was notices in month $4(47.3 \%)$, while the lowest in month 1,11 and 10 . It can be concluded that there is a huge problem with operation of this device. It can be caused by many factors, particular attention should be paid to the following groups of factors $[3,11]$ :

- $\quad$ Problems with demand of pig iron - similar to the previous factor, it can be one of cause of low value. Changes in demand that occur suddenly may interrupt the implementation of the production plan. Unfortunately, this group of factors is not affected by the blast furnace department.

- Quality of materials - proper preparation of the basic raw material for the production of pig iron, sinter, has a significant impact on the blast furnace process. Its chemical composition, mainly the content of the basic element or iron, has an impact on the yield of pig iron, i.e. indirectly on the volume of production. Therefore, the use of this low-quality material increases the amount of by-products (slag) and reduces the yield of pig iron.

- Quality and type of fuels - the use of high quality fuel, which is blast furnace coke, allows for optimal conduct of the blast furnace process, maintaining its parameters at the most favourable level. The use of cheaper substitutes for this fuel with appropriate quantities will not have a significant impact on the volume of production, but exceeding the optimal size may worsen the operation of the device and extend the melting time.

- $\quad$ Operating parameters of the blast furnace - appropriate distribution of materials and maintaining parameters at a constant, optimal level results in even operation of the device. Disruption of these parameters can have a significant impact on the duration of the melt, processes in the furnace, which can also cause disruptions in the volume of production.

During the analysis of quality of pig iron two critical parameters were taken into account: Si and S content in pig iron. High quality of pig iron can be defined as the pig iron with the content of $\mathrm{Si}$ and $\mathrm{S}$ on the proper level. The results of the analysis of Quality Indicator (see Figure 3) show that the level of quality indicator is $93.5 \%$ on average and is only a bit lower than standard value. It can be said that the average value was exceeded only in 4 months (the highest in month 9) and the lowest value was noticed in month 10. 
In many cases the problem with the quality of pig iron was caused by problems with quality of charge materials and fuels but also by break-down of equipment. The amount of production that was treated as a loss is classified as scrap which can be forwarded to reprocessing.

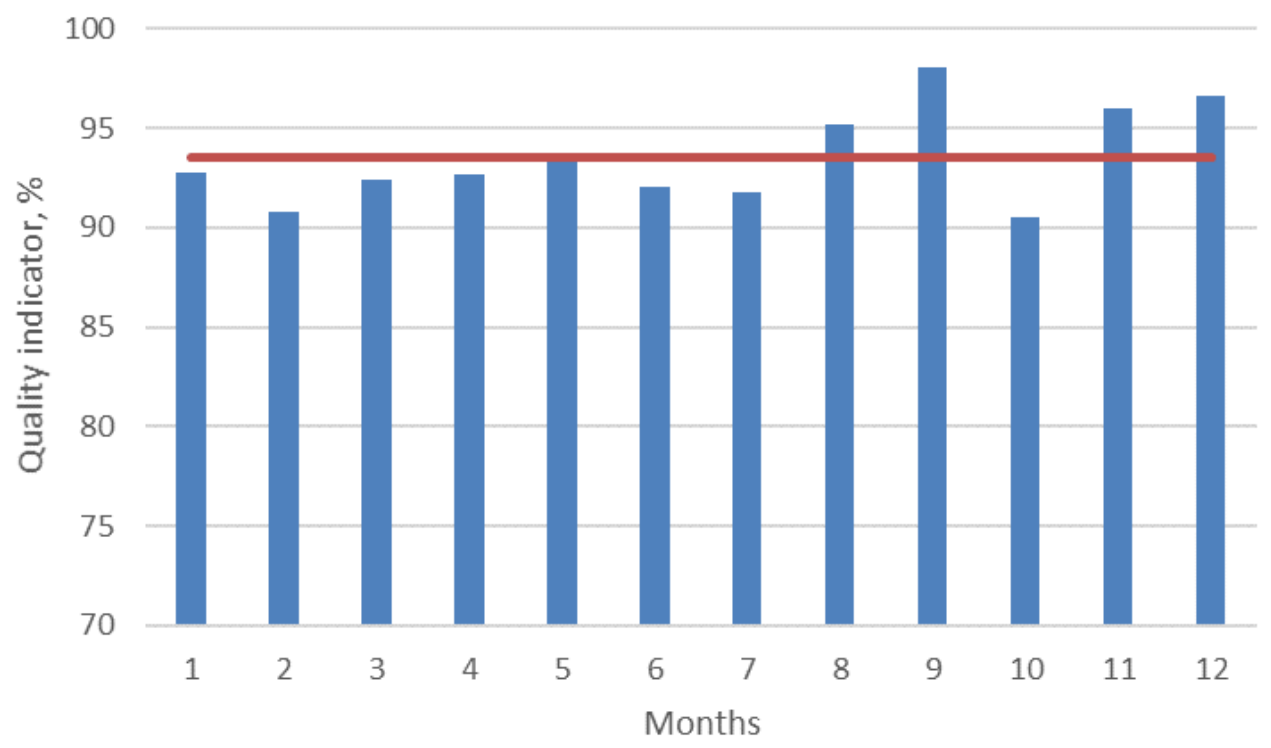

Figure 3 Value of Quality Indicator of tested blast furnace during study period (own study based on [10])

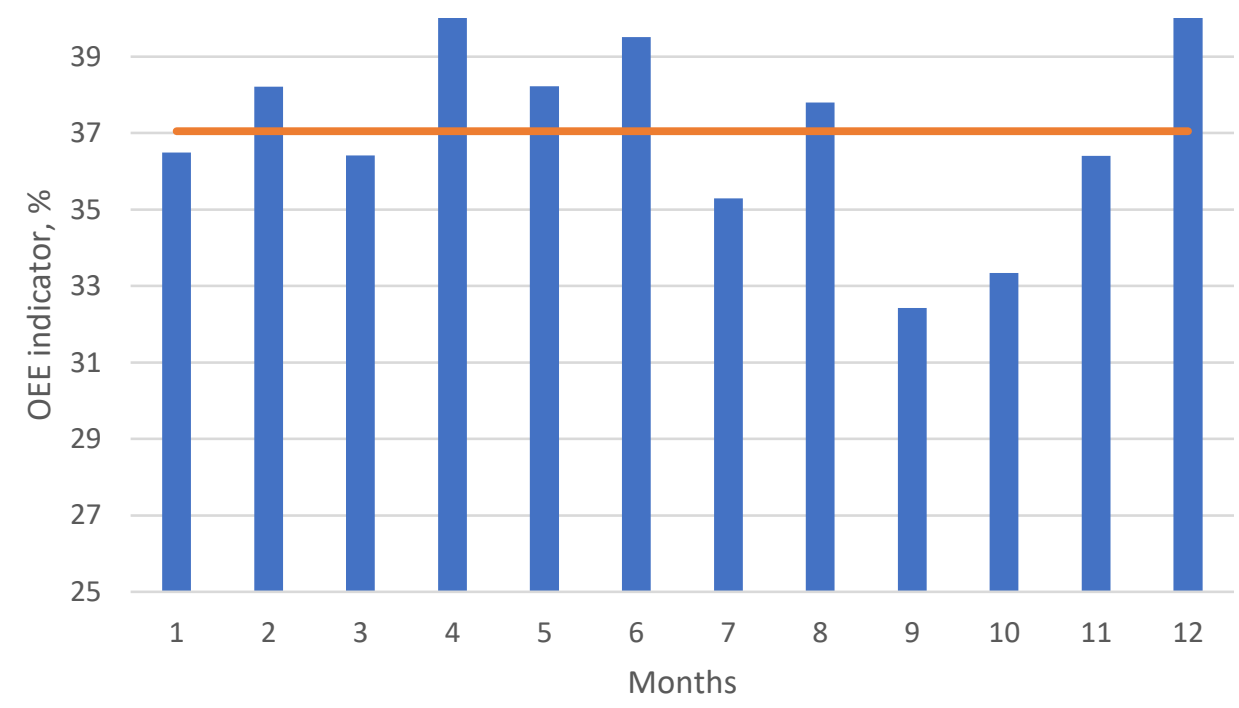

Figure 4 Value of Overall Equipment Effectiveness indicator of tested blast furnace during study period (own study based on [10])

Based on the results of the analysis presented in Figure 4 it can be said that the level of OEE indicator was significantly lower than theoretical value ( $85 \%)$ and average value on the world (60\%). Analysed blast furnace reached the value at app. $37 \%$. It must be underlined that only in 6 months average value was exceeded. The highest values were noticed in months 12 and 4 (over $40 \%$ ), while the lowest in months 9 (under $33 \%$ ) and $10(33.3 \%)$. It must be underlined that indicator is product of three previous indicators so three main elements decease value of OEE: 
- $\quad$ Accessibility - the analysis showed that app. $88 \%$ of all shift work found is accessible. It is caused by problems with maintenance of blast furnace: this device is not new, it must be overhauled periodically (current renovations). Many technological and mechanical breaks were noticed, what was caused by various failures. Periodically also problems with demand for pig iron were observed.

- Utilization - average utilization was noticed at the level of $45 \%$, what means that value was very low. It was the main problem of lower value of OEE. This situation was cased by a few factors: problems with demand of pig iron, poor quality of raw materials and fuels and operating parameters of the blast furnace.

- $\quad$ Quality - quality of pig iron in the study period was on the high level (app. $93.5 \%$ ). It must be added that main quality factors in blast furnace process are: quality of raw materials and fuels and operating parameters of the blast furnace. The poorer quality of raw materials, the more fuels used in process and the more problem with production time and parameters of the process.

\section{CONCLUSION}

According to the analysis of effectiveness of blast furnace using OEE it can be concluded that in comparison to the average values of OEE in production companies value of the parameter is very low. The level of effectiveness is influenced by many different factors that often are not depend on the blast furnace department. Among them there are $[3,11]$ : external (situation on the steel market in Poland and the world, demand for raw materials in the world, quality of materials) or internal (the age of the device, work organization of blast furnace and its parameters). The results of the analysis should be compared to the results of other blast furnaces device working in the world but it is difficult to find such results. This kind of analysis requires a lot of time but it can bring interesting conclusions.

\section{REFERENCES}

[1] WOROBJOW, L. Produktywność i efektywność przedsiębiorstwa. Bydgoszcz: Polskie Stowarzyszenie Zarządzania Wiedzą, Seria: Studia i Materiały, Vol. 5, 2006.

[2] BADURA, H., MICHNA, A., CZERWIŃSKI, S. Złożoność wielowymiarowego pomiaru efektywności funkcjonowania przedsiębiorstw - przyczynek do dalszych badań. Systemy wspomagania w inżynierii produkcji, Górnictwo - perspektywy i zagrożenia, 2016, vol. 5, no. 1, pp. 248-254.

[3] KARDAS, E. Analiza wybranych wskaźników efektywności pracy wielkiego pieca. Systemy Wspomagania w Inżynierii Produkcji, 2018, vol. 7, no. 3, pp. 217-227.

[4] CZERSKA, J. Improving of Value Stream. Warsaw: Printing Huose. Difin, 2009.

[5] BORKOWSKI, S., ULEWICZ, R. Production management. Production systems. Sosnowiec: Printing House „Humanitas”, 2009.

[6] INGALDI, M., DZIUBA, S.T. Modernity Evaluation of the Machines Used During Production Process of Metal Products. In METAL 2015: 24th International Conference on Metallurgy and Materials. Ostrava: TANGER, 2015, pp. 1908-1914.

[7] BARTECKI, K., KRÓL, D., SKOWROŃSKI, J. Wyznaczanie kluczowych wskaźników wydajności procesu produkcyjnego - cz.l: badania teoretyczne. Pomiary Automatyka Robotyka, 2018, vol. 22, no. 3, pp. 5-13.

[8] GARZA-REYES, J.A., ELDRIDGE, S., BARBER, K.D., SORIANO-MEIER, H. Overall equipment effectiveness $(\mathrm{OEE})$ and process capability (PC) measures: A relationship analysis. International Journal of Quality \& Reliability Management, 2010, vol. 27, no. 1, pp. 48-62.

[9] YLIPÄÄ, T., SKOOGH, A., BOKRANTZ, J., GOPALAKRISHNAN, M. Identification of maintenance improvement potential using OEE assessment. International Journal of Productivity and Performance Management, 2017, vol. 66, no. 1, pp. 126-143,

[10] Information materials, 2019. Blast Furnace Department of Steelworks X.

[11] KARDAS, E. Evaluation of efficiency of working time of equipment in blast furnace department. Journal of Achievements in Materials and Manufacturing Engineering, 2012, vol. 55, no. 2, pp. 876-880. 